\title{
PENGEMBANGAN BAHAN AJAR STATISTIKA UNTUK MENGEMBANGAKAN KEMAMPUAN PEMAHAMAN MATEMATIS MAHASISWA PENDIDIKAN ANAK USIA DINI PADA MATA KULIAH STATISTIKA
}

\author{
Yenni \\ Universitas Muhammadiyah Tangerang \\ yennisaja@outlook.com
}

\begin{abstract}
ABSTRAK
Penelitian ini bertujuan untuk mengembangkan kemampuan pemahaman matematis mahasiswa Program Studi Pendidikan Guru Pendidikan Anak Usia Dini (PGPAUD) pada mata kuliah Statistika. Pemamahaman matematis mahasiswa PGPAUD rendah karena ketidakminatan mereka dalam menempuh mata kuliah yang dinilai melelahkan. Berdasarkan hal tersebut, penanganan yang dilakukan adalah dengan menyajikan bahan ajar yang representative dan mampu mengembangkan kemampuan pemahaman matematis. Jenis Penelitian ini adalah penelitian pengembangan, berupa pengembangan bahan ajar. Sumber data ditentukan secara purposive dengan maksud dapat memperoleh hasil yang lebih maksimal. Prosedur pengembangan dimulai dengan fase investigasi awal; fase desain; fase realisasi/konstruksi; fase tes, evaluasi dan revisi serta fase implementasi. Berdasarkan hasil analisis diperoleh data bahwa nilai uji materi ajar sangat kuat, uji pendidikan sangat kuat, uji kepraktisan sangat praktis dan uji keefktifan sangat efektif. Dengan demikian, bahan ajar statistika yang telah disusun layak dipergunakan untuk mengembangkan kemampuan pemahman matematika.
\end{abstract}

Kata Kunci: bahan ajar, pemahaman matematis, pengembangan

\begin{abstract}
This study aims to develop students' mathematical understanding of the Early Childhood Education Teacher Education Study Program (PGPAUD) in Statistics courses. PGPAUD students mathematical pemamahaman low because of their discomfort in taking courses considered grueling. Based on this, the handling is done by presenting the teaching materials representative and able to develop the ability of mathematical understanding. Type This research is a development research, in the form of development of teaching materials. Data sources are determined purposively in order to obtain maximum results. The development procedure begins with the initial investigative phase; Design phase; Phase of realization/construction; Test phase, evaluation and revision and implementation phase. Based on the analysis results obtained data that the value of teaching material test is very strong, education test is very strong, practicality test is very practical and effectiveness test is very effective. Thus, the statistical teaching materials that have been prepared deserve to be used to develop the ability pemahman mathematics.
\end{abstract}

Keywords: development, mathematical understanding, teaching materials.

\section{PENDAHULUAN}

Penelitian ini dilatarbelakangi oleh ketidakminatan mahasiswa program studi Pendidikan Guru Pendidikan Anak Usia Dini (PGPAUD) terdahap mata kuliah matematika dan sejenisnya, termasuk didalamnya mata kuliah Statistika. Ketidakminatan ini berimbas langsung pada "tidak seleranya" mahasiswa untuk 
mengikuti mata kuliah statistika, sehingga berdampak malas dan rendahnya pemahaman matematis mahasiswa terhadap materi statistika. Kehadiran mahasiswa tidak sepenuhnya dilakukan dengan hati, namun sebagian besar karena kewajiban mengikuti mata kuliah. Ada semacam keterpaksaan yang tergambar disana. Hasil percakapan dengan beberapa mahasiswa, beberapa diantaranya memang menghindari mata kuliah berbau matematika, ada juga yang menyukai, namun persentasenya jauh lebih rendah daripada yang tidak menyukai. Mata kuliah yang syarat dengan hitungan dinilai mahasiswa melelahkan. Alasan lain yang dikemukakan mahasiswa adalah karena jenis penelitian yang digunakan di PGPAUD cenderung berupa penelitian tindakan kelas, penelitian kualitatif dan pengembangan yang "tidak terlalu membutuhkan" matematika dan statistika.

Mata kuliah statistika adalah salah satu mata kuliah wajib pada program studi PGPAUD. Mata kuliah statistika terdapat di semester IV, dan dilanjutkan dengan mata kuliah statistika pendidikan pada semester V. Mata kuliah statistika memiliki peranan yang sangat strategis bagi mahasiswa dalam konsep penelitian. Bahasan dalam mata kuliah ini memberikan pengetahuan dan pengalaman mendasar dalam mengumpulkan, menyajikan data dan mengolah data penelitian, serta merupakan mata kuliah prasarat bagi mata kuliah Statistika kependidikan. Materi yang dibahas pada mata kuliah ini adalah: 1) Data Statistik, meliputi pengertian statistik dan statistika, Jenis-jenis data, cara pengumpulan data, serta populasi dan sampel, 2) Penyajian Data Statistik, meliputi penyajian data dalam bentuk tabel serta penyajian data dalam bentuk diagram, 3) Ukuran Pemusatan, Penyebaran dan Dispersi Data, meliputi mean, modus, median, kuartil, desil, persentil, 4) Kemiringan dan Keruncingan Kurva, dan 5) normalitas dan Homogenitas data.

Agar proses pembelajaran berlangsung dengan bermakna dan optimal, maka kegiatan belajar harus direncanakan sedemikian rupa demi memacu minat peserta didik. Hal ini sejalan pendapat Khomsiatun dan Retnawati (2015), bahwa kegiatan pembelajaran yang dirancang dengan baik berpengaruh terhadap hasil belajar peserta didik. Proses dalam pembelajaran sangat berarti dalam menanamkan pengatahuan baru. Dengan demikian, pembelajaran merupakan pengaturan pengalaman siswa yang disengaja untuk memperoleh kemampuan tertentu. 
Kemampuan tersebut bervariasi secara kualitatif mulai dari mengingat hingga menemukan pengetahuan baru. Hal tersebut, tergantung dari bagaimana seorang pengajar merancang pembelajaran. Secara jelas terungkap, bahwa seorang pengajar wajib mengetahui kebutuhan peserta didiknya.

Rancangan pembelajaran yang baik harus di dukung dengan media yang baik pula. Media yang dipilih untuk dapat mengembangkan pemahaman matematis mahasiswa PGPAUD pada penelitian ini adalah bahan ajar berupa modul. Modul merupakan bahan ajar cetak yang dirancang untuk dapat dipelajari secara mandiri oleh peserta didik secara mandiri, karena didalamnya telah dilengkapi dengan petunjuk yang berfungsi menuntun peserta didik agar dapat belajar secara mandiri (Dharma, 2008; Amalia, 2016). Prastowo (2011) mengatakan bahan ajar adalah segala sesuatu yang dapat digunakan untuk membantu guru atau dosen dalam melaksanakan kegiatan belajar mengajar. Bahan ajar bersifat sistematis, yang menampilkan sosok utuh dari kompetensi yang akan dikuasai peserta didik dan digunakan dalam proses pembelajaran dengan tujuan untuk perencanaan dan penelaahan implementasi pembelajaran.

Dharma (2011) mengkategorikan bahan ajar dapat dikatakan baik apabila mengcakup lima hal, yaitu 1) self instructional, artinya bahwa modul harus bisa membuat peserta didik belajar sendiri dan tidak bergantung pada pihak lain. 2) self contained, artinya bahwa bahan ajar harus menyajikan materi secara utuh, sehingga peserta didik dapat belajar dengan tuntas, karena materi dan kompetensi yang harus tercapai berada dalam satu paket. 3) stand alone, artinya bahwa peserta didik dapat menggunakan modul baik secara bersama-sama, maupun hanya sendiri dengan tidak memerlukan bantuan dari media lain. 4) adaptive, artinya bahwa bahan ajar harus fleksibel penggunaannya, mengikuti perkembangan teknologi dan dapat diguakan hingga jangka waktu tertentu. 5) user friendly, artinya bahan ajar harus mudah dipahamahami oleh peserta didik.

Kemampuan pemahamanan matematis sangat diperlukan sebagai salah satu aspek untuk dapat mencapai hasil maksimal pada mata kuliah Statistika. Untuk dapat menumbuhkan kemampuan pemahaman matematis mada mata kuliah statistika, kreatifitas dosen sangat dibutuhkan. Salah satunya dengan menyusun 
bahan ajar yang berupa modul. Bahan ajar statistika dikemas dengan memuat ringkasan materi statistika. Dalam bahan ajar ini, selain ringkasan materi, mahasiswa juga diharuskan berlatih dengan mandiri atau berkelompok untuk melatih pengetahuan yang diperoleh agar manfaatnya dapat segera diaplikasikan ke persoalan statistik. Soal yang disajikan dalam bahan ajar ini disusun untuk dapat mengembangkan kemampuan pemahaman matematis mahasiswa dalam mata kuliah statistika. Pemahaman matematis adalah kemampuan untuk mengekspresikan atau mengungkapkan dalam bentuk lisan maupun tulisan apa yang telah diperoleh dengan bentuk lain yang merupakan padanan. Kemampuan pemahmana matematis wajib dikuasai oleh mahasiswa setelah mereka menempuh mata kuliah statistika. Kemampuan pemahaman matematis akan sangat berpengaruh pada hasil belajar mahasiswa secara keseluruhan.

Berdasarkan latar belakang masalah tersebut, maka tujuan dalam penelitian ini adalah mengembangkan produk berupa bahan ajar pada mata kuliah statistika materi penyajian data untuk mengembangkan kemampuan matematis mahasiswa. Indikator pemahaman matematis yang dikembangkan dalam bahan ajar ini meliputi empat indikator, adalah sebagai berikut : 1) Menyatakan ulang sebuah konsep, 2) Kemampuan menyajikan konsep dalam berbagai bentuk representasi matematis, 3) Kemampuan menggunakan konsep untuk menyelesaikan suatu permasalahan matematis, dan 4) Memberi contoh dan bukan contoh dari suatu konsep.

\section{METODE PENELITIAN}

Jenis penelitian ini adalah pengembangan (Development Research). Penelitian pengembangan adalah penelitian untuk mengembangkan dan menghasilkan produk-produk pendidikan berupa materi, media, alat, strategi pembelajaran, evaluasi, dan sebagainya untuk mengatasi masalah pendidikan, dan bukan untuk menguji teori (Rusaffendi dalam Safitri, 2016). Penelitian ini bertujuan untuk menghasilkan suatu produk berupa bahan ajar yang bisa mengembangkan kemampuan pemahaman matematis mahasiswa dalam mata kuliah statistika. Nieveen (dalam Amalia dan Retnawati, 2015) mengatakan, dalam menentukan kualitas hasil penelitian pengembangan, komponen-komponen produk pendidikan dikatakan valid apabila didasarkan pada state of the art knowledge rasional teoritik 
yang kuat (validitas isi) dan semua komponen harus terkait secara konsisten satu dengan yang lain (validitas konstruk). Sedangkan komponen produk pendidikan dikatakan praktis apabila guru atau dosen dapat mempertimbangkan alat atau bahan yang dapat dipakai dan mudah bagi guru/dosen dan peserta didik untuk menggunakannya.

Penentuan sumber data dilakukan dengan teknik purposive. Teknik ini dipilih karena sumber data ditentukan oleh peneliti dengan pertimbangan tertentu, dengan maksud untuk memaksimalkan informasi/data.

Tahap-tahap penelitian yang dilakukan dalam penelitian ini mengacu pada Plomp (dalam Sudarwan dan Retnawati, 2015). Tahapan tersebut terdiri dari lima fase dengan urutan sebagai berikut: 1) Fase investigasi awal, 2) Fase desain, 3) Fase realisasi/konstruksi, 4) Fase tes, evaluasi dan revisi, dan 5) Fase implementasi. Namun demikian, pada penelitian ini tahap dibatasai hanya sampai dengan tahapan ke-empat, yaitu tes, evaluasi dan revisi.

Waktu pelaksanaan penelitian ini di semester Ganjil Tahun Akademik 2016/2017. Prosedur pengembangan dimulai dari fase 1, yaitu tahap investigasi awal. Pada tahap ini peneliti melakukan observasi untuk mengumpulkan berbagai informasi sebagai sumber data. Terdapat empat hal yang peneliti lakukan pada tahap ini. Pertama berkaitan dengan kemampuan pemahaman matematis mahasiswa pada mata kuliah statistika. Focus dari pencarian informasi di sini adalah bagaimana kemampuan pemahaman matematis mahasiswa program studi PGPAUD. Kedua, data berkaitan dengan bahan ajar yang digunakan sebelumnya. Focus pada informasi kedua ini adalah, apakah bahan ajar mata kuliah statistika tahun sebelumnya telah mencakup kemampuan pemahaman matematis. Identifikasi ketiga adalah studi literartur tertang pengembangan bahan ajar, dan hal ke empat adalah studi literature tentang kemampuan pemahaman matenatis.

Memasuki fase desain, peneliti telah merancang draft bahan ajar, yang memuat ringkasan seluruh materi mata kuliah statistika secara sistematis, dengan rincian materi berdasarkan urutan Rencana Pembelajaran Semester (RPS). Setiap bab memuat judul bab, judul materi, tujuan yang diharapkan, materi, contoh soalsoal dan latihan-latihan yang mengerucut ke kemampuan pemahaman matematis 
pada materi statistika yang sedang dibahas. Langkah-langkah yang dilakukan meliputi : 1) pemilihan materi sesuai RPS; 2) pemilihan format, format yang dipilih adalah kertas dengan desain orientation Portrait, paper size A4 dengan width 8,27" dan height 11,69". Ukuran Magins Top 1,18"; left 1,18", bottom 1,18" dan right 1,18; jenis kertas 80 gram dengan format Portabel Document Format (PDF) berjumlah 81 halaman, dan 3) menyusun soal-soal statistika dengan indikator kemampuan pemahaman matematis.

Selanjutnya, untuk fase pengembangan ke tiga yaitu fase realisasi/kontruksi. Produk awal yang disusun oleh peneliti diberi nama Draft I. Selanjutnya, Draft I diserahkan untuk divalidasi ke pakar. Pakar terdiri dari dua orang, yaitu ahli materi untuk memeriksa kevalidan materi statistika dan ahli pendidikan untuk memeriksa kevalidan soal-soal latihan yang memuat kemampuan pemahaman matematis

Terakhir fase tes, evaluasi dan revisi. Setelah mendapat masukkan dari kedua ahli, draft direvisi dan diberi nama draft II. Draft II selanjutnya diujicobakan ke mahasiswa program studi Pendidikan Matematika yang berjumlah lima orang dengan kriteria mahasiswa tersebut telah menerima mata kuliah statistika. Uji coba ke mahasiswa pendidikan matematika bertujuan untuk memperoleh masukkan dari mahasiswa, dari segi kepraktisan. Masukkan mahasiswa yang berupa angket selanjutnya menjadi bahan revisi untuk Draft II. Hasil revisi Draft II dinamakan Draft III. Draft III selanjutnya digunakan sebagai bahan ajar pada mata kuliah Statistika pada Program Studi Pendidikan Anak Usia Dini semester III tahun Akademik 2016/2017. Di akhir pembelajaran, mahasiswa PGPAUD diminta untuk mengisi angkes repon mahasiswa, yang bertujuan menyempurnakan draft III.

Rata-rata penilaian validasi bahan ajar berdasarkan Hobri (dalam Amelia dan Retnawati, 2015) sebagai berikut:

$$
\mathrm{V}_{\mathrm{m}}=\frac{\sum_{i=1}^{n} A_{i}}{n} \text {, dengan } \mathrm{V}_{\mathrm{m}}=\text { rata-rata validasi ahli, dan } \mathrm{A}_{\mathrm{i}} \text { adalah rata-rata }
$$

aspek ke I, dan n adalah banyaknya aspek. Untuk persentase penilaian validasi ahli dirumuskan dengan:

$$
\mathrm{P}=\frac{\text { jumlah skor tiap aspek }}{\text { skor maksimal }} x 100 \%
$$


Interpretasi skor berdasarkan Riduwan (dalam Safitri, 2016) sebagai berikut:

Tabel 1. Kriterian Interpretasi skor

\begin{tabular}{cc}
\hline Kriteria $($ dalam \%) & Klasifikasi \\
\hline $80<\mathrm{P} \leq 100$ & Sangat Kuat \\
$60<\mathrm{P} \leq 80$ & Kuat \\
$40<\mathrm{P} \leq 60$ & Cukup \\
$20<\mathrm{P} \leq 40$ & Lemah \\
$0<\mathrm{P} \leq 20$ & Sangat Lemah \\
\hline
\end{tabular}

Untuk menentukan kategori kepraktisan bahan ajar oleh mahasiswa, digunakan konversi data berdasarkan kriteria yang disajikan dalam table berikut (Khomsiatun, retnawati, 2015)

Tabel 2. Kategori Kepraktisan Bahan Ajar

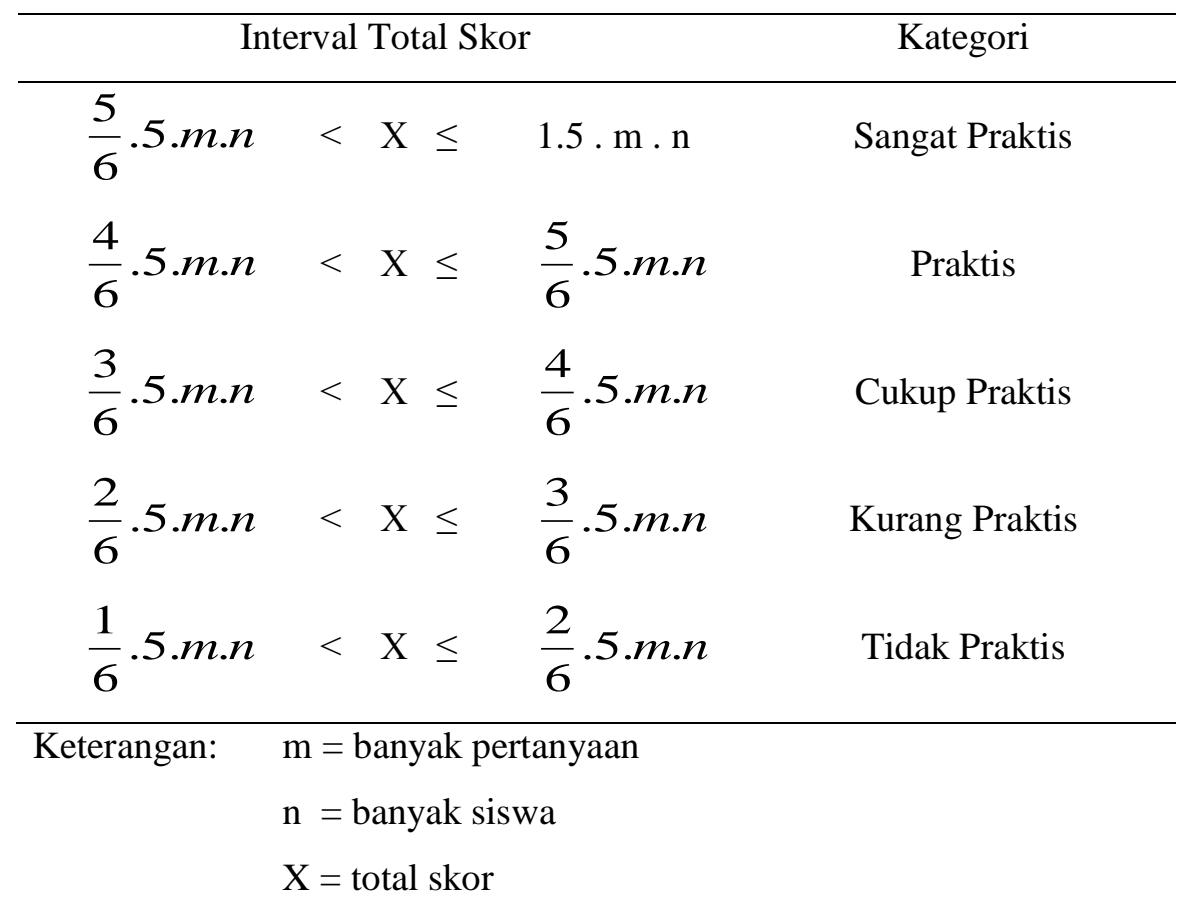

Sedangkan untuk mengetahui keefektifan bahan ajar digunakan ketuntasan nilai dengan batas nilai minimal B. Nilai B adalah nilai yang berada pada interval 68-79. Untuk menentukan kategori keefektifan perangkat. Digunakan table sebagai berikiut (Khomsiatun, Retnawati, 2015) 
Tabel 3. Kategori Kefektifan Bahan Ajar

\begin{tabular}{|c|c|}
\hline Ketuntasan & Kategori \\
\hline Ketuntasan $\geq 80 \%$ & Sangat efektif \\
\hline Ketuntasan $<80 \%$ & Efektif \\
\hline
\end{tabular}

\section{HASIL PENELITIAN DAN PEMBAHASAN}

Setelah Draft I disusun oleh peneliti, selanjutnya Draft I diserahkan kepada pakar untuk divalidasi. Tabel 4 berikut adalah hasil uji validasi pakar:

Tabel 3. Kategori Kefektifan Bahan Ajar

\begin{tabular}{ccc}
\hline Uji & Persentase & Klasifikasi \\
\hline Ahli Materi & 83,06 & Sangat Kuat \\
Ahli Pendidikan & 80,77 & Sangat Kuat \\
\hline
\end{tabular}

Hasil analiss dari segi kepraktisan, diperoleh skor 221 yang berarti sangat praktis. Mahasiswa menilai bahwa materi yang disajikan jelas. Latihan soal dapat dikerjakan berdasarkan materi yang sudah disajikan. Poin penting yang lain bahwa mahasiswa tertarik untuk belajar statistik. Dengan demikian ada minat mahasiswa untuk belajar statistika.

Sedangkan dari segi keefektifan, dari 22 mahasiswa, terdapat 18 siswa yang memperoleh nilai akhir B dan A, atau sebesar $81,82 \%$. Artinya, bahan ajar sangat efektif.

Berdasarkan fase-fase yang dilakukan pada penelitian pengembangan, diperoleh data sebagai berikut:

Fase 1 investigasi awal. Empat hal yang ditemukan oleh peneliti yaitu: 1) Data kemampuan pemahaman matematis mahasiswa pada mata kuliah statistika. Data yang digunakan adalah data pada semester-semester sebelumnya. Diperoleh data, bahwa kemampuan pemahaman matematis mahasiswa PGPAUD belum maksimal. Yang peling menonjol adalah ketika diminta untuk membuat bentuk representasi matematis, sebagian besar mahasiswa menjawab dengan jenis yang sama. Hal tersebut terjadi karena mahasiswa menjawab sesuai contoh soal yang diberikan oleh dosen, meskipun telah diterangkan bahwa terdapat cara lain selain cara penyelesaian pad contoh. 2) Data berkaitan dengan bahan ajar yang digunakan 
sebelumnya. Diperoleh data, bahwa pada perkuliahan mata kuliah statistika terdahulu, bahan ajar hanya berupa lembar materi, yang memuat latihan secara umum, belum meng-cover kemampuan pamahaman matematis. Dari data ini, peneliti berpikir bahwa kemampuan pemahaman matematis PGPAUD tidak maksimal dan cenderung rendah disebabkan dosen tidak memaksimalkan dalam proses latihan-latihan terstruktur yang tersedia pada lembar materi.

Fase II: Desain. Peneliti telah merancang draft bahan ajar, yang memuat ringkasan seluruh materi mata kuliah statistika secara sistematis, dengan rincian materi berdasarkan urutan Rencana Pembelajaran Semester (RPS). Setiap bab memuat judul bab, judul materi, tujuan yang diharapkan, materi dan latihan yang mengerucut ke kemampuan pemahaman matematis pada materi statistika yang sedang dibahas. Berikut ini adalah contoh halaman yang terdapat dalam bahan ajar.

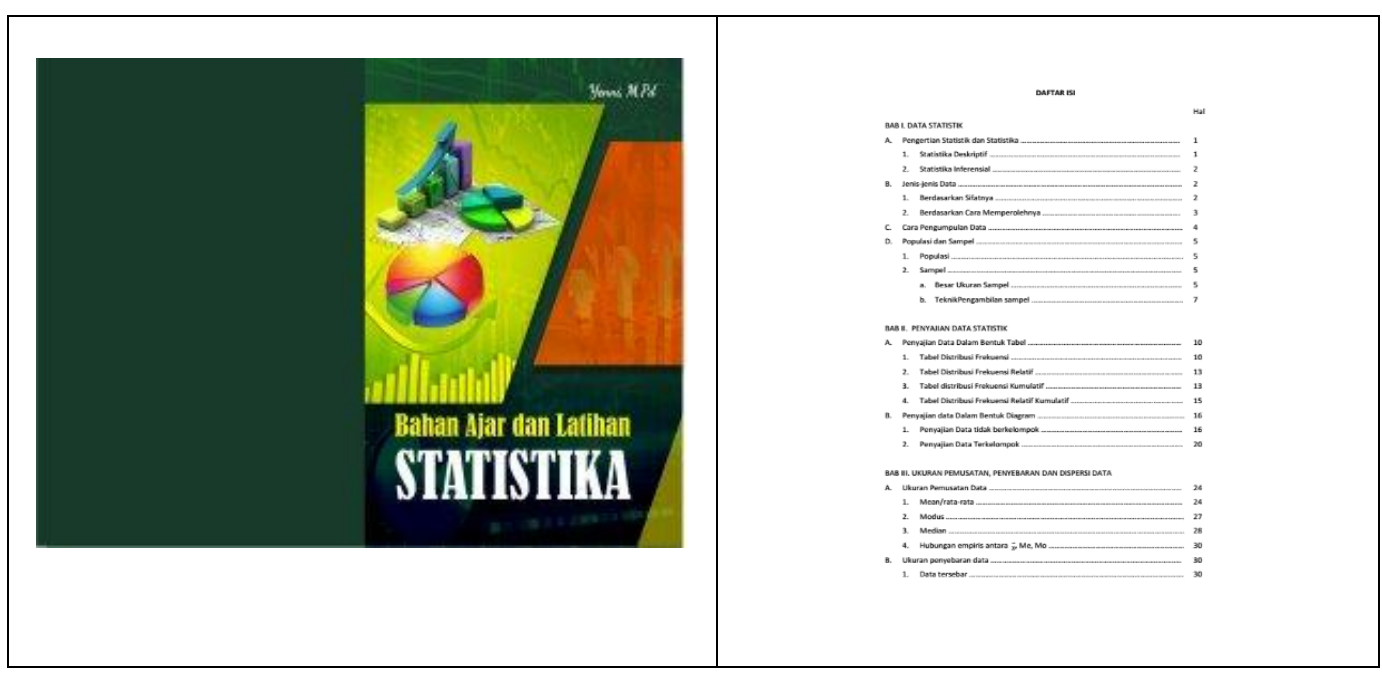

Gb 1. Cover Depan

Gb 2. Daftar Isi

Gambar 1 adalah cover depan. Cover ini tidak mengalami perubahan hingga draft III. Gambar 2 adalah halaman daftar isi. Pada halaman ini tertulis seluruh isi bahan ajar, mulai dari cover dalam, kata pengantar, inti materi mata kuliah statistika per bab, daftar pustaka dan lampiran. 


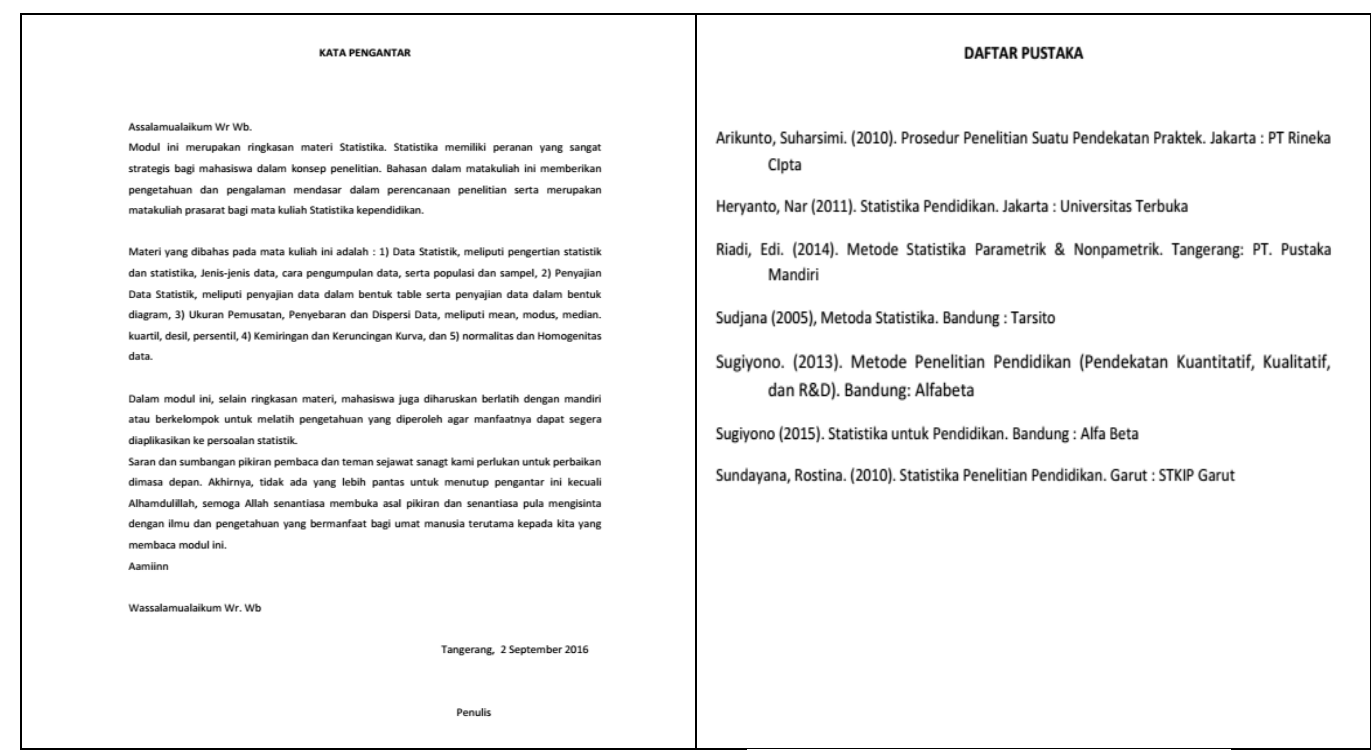

Gb 3. Kata Pengantar

Gb 4. Daftar Pustaka

Gambar 3 adalah kata pengantar, dan gambar 4 adalah daftar pustaka. Pada kata pengantar terdapat terjadi satu kali perubahan, yaitu ungkapan yang menegaskan bahwa bahan ajar ini bertujuan mengembangkan kemampuan pemahaman matematis mahasiswa dalam mata kuliah statistika.

\begin{tabular}{|c|c|}
\hline $\begin{array}{c}\text { BAB ॥ } \\
\text { PENYAIIAN DATA STATISTIK }\end{array}$ & $\begin{array}{c}\text { BAB II } \\
\text { PENYAIIAN DATA STATISTIK }\end{array}$ \\
\hline $\begin{array}{l}\text { Setelah mempelajari bab II, Mahasiswa dapat: } \\
\text { 1. Menyajikan data dalam bentuk tabel dan diagram untuk data tidak berkelompok } \\
\text { 2. Menyajikan data dalam bentuk tabel dan diagram untuk data berkelompok } \\
\text { 3. Membedakan distribusi frekuensi relatif dan kumulatif. } \\
\text { 4. Membuat tabel Distribusi frekuensi relatif dan kumulatif } \\
\text { 5. Menyusun data terkelompok ke dalam bentuk tabel distribusi frekuensi } \\
\text { 6. Menyusun data tak terkelompok ke dalam bentuk tabel distribusi frekuensi } \\
\text { 7. Membuat histogram dan poligon frekuensi. } \\
\text { 8. Membuat ogive } \\
\text { Penyajian Data Dalam Bentuk Tabel } \\
\text { Setelah data terkumpul data harus disajikan sedemian rupa agar lebih mudah di analisis } \\
\text { dan dibaca. Beberapa cara dapat digunakan untuk menyajikan data. } \\
\text { 1. Tabel Distribusi frekuensi } \\
\text { Pada pembuatan table distribusi frekuensi , tidak ada ketentuan baku bagaimana } \\
\text { bentuk table, urutan elemen, serta apa saja yang harus ada. Namun demikian, ada } \\
\text { beberapa hal yg harus diperhatikan agar suatu table distribusi frekuensi dapat } \\
\text { memberikan informasi yang baik. } \\
\text { a. jumlah kelas sebaiknya tidak terlalu banyak, tidak pula terlalu sedikit, biasanya }\end{array}$ & 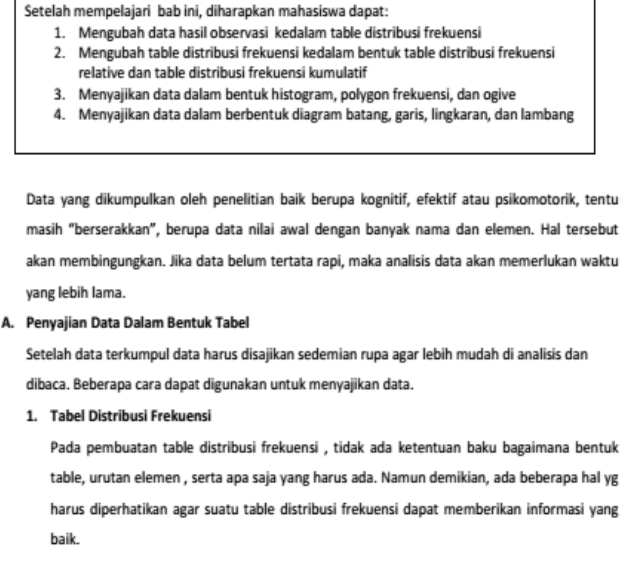 \\
\hline
\end{tabular}

Gb 5. Indikator Pencapaian bab II sebelum revisi
Gb 6. Indikator Pencapaian Bab II setelah revisi 
Pada setiap bab, peneliti menuliskan tujuan yang harus dicapai setelah mahasiswa mempelajari bab tersebut. Pada tujuan bab II, terdapat revisi seperti pada gambar 5 dan gambar 6.

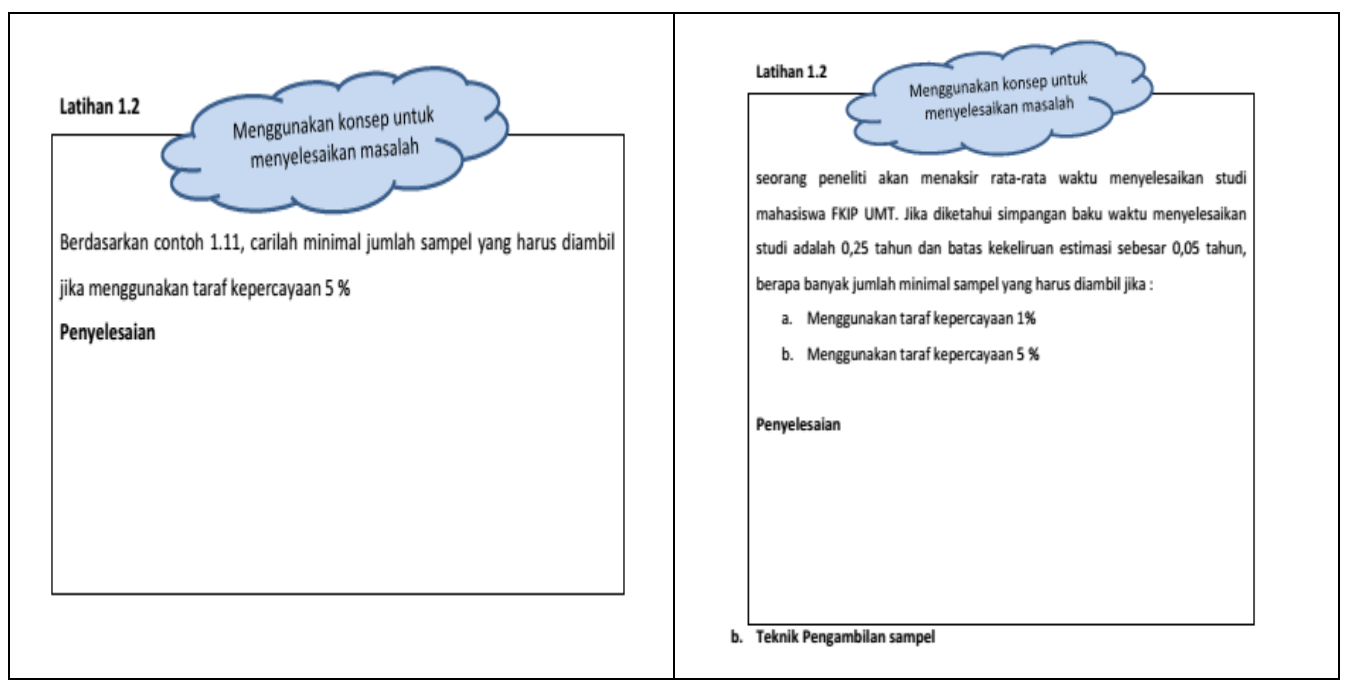

Gb 7. Latihan Kemampuan Menggunakan Konsep untuk Menyelesaikan Masalah Sebelum Revisi
Gb 8. . Latihan Kemampuan Menggunakan Konsep untuk Menyelesaikan Masalah Setelah Revisi

kemampuan menggunakan konsep untuk menyelesaikan masalah sebelum direvisi. Sebelum direvisi pertanyaan pada latihan 1.2 berkaitan dengan contoh soal yang telah dibahas sebelumnya. Hasil revisi, soal harus diperjelas, sehingga mahasiswa dapat membaca soal secara utuh, dan dapat menggunakan rumus yang tepat untuk menyelesaikan soal tersebut. Hasil soal yang telah direvisi disajikan pada gambar 8 .

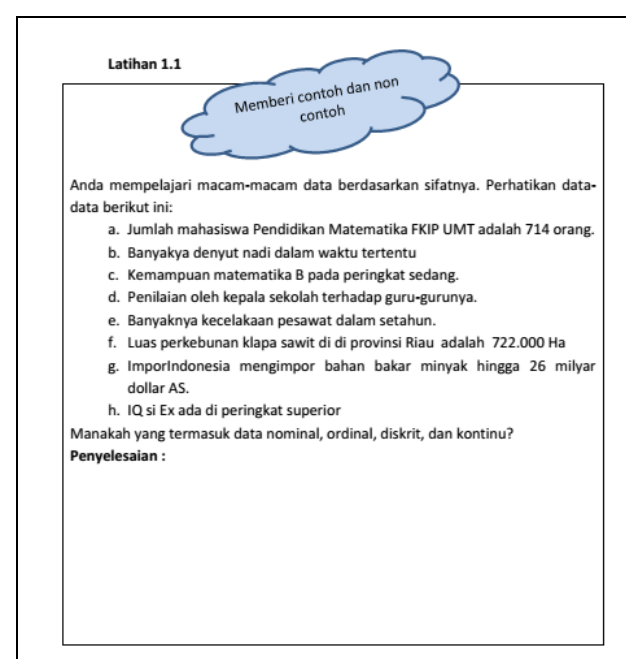

Gb 9. Latihan Kemampuan Memberi Contoh dan Non-Contoh Sebelum Revisi

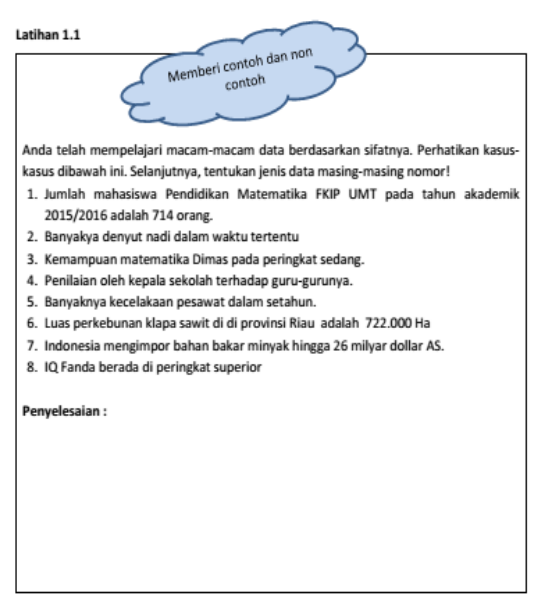

Gb 10. Latihan Kemampuan Memberi Contoh dan Non-Contoh Setelah Revisi 
Gambar 9 menunjukkan contoh latihan yang bertujuan mengembangkan kemampuan memberi contoh dan non-contoh sebelum revisi. Revisi dilakukan karena kalimat dinilai kurang efektif dan kurang komunikatif. Hasil revisi ditunjukkan pada gambar 10 .

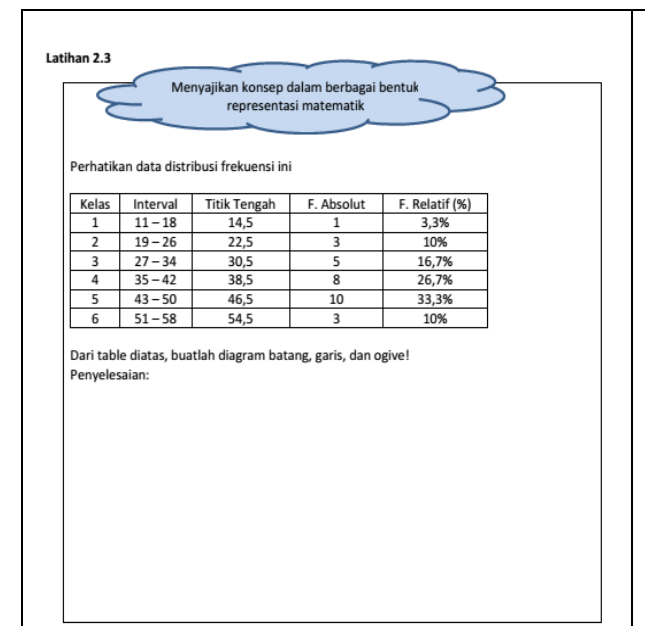

Gb 11. Latihan Kemampuan Menyajikan Konsep dalam Berbagai Bentuk Representasi Matematis

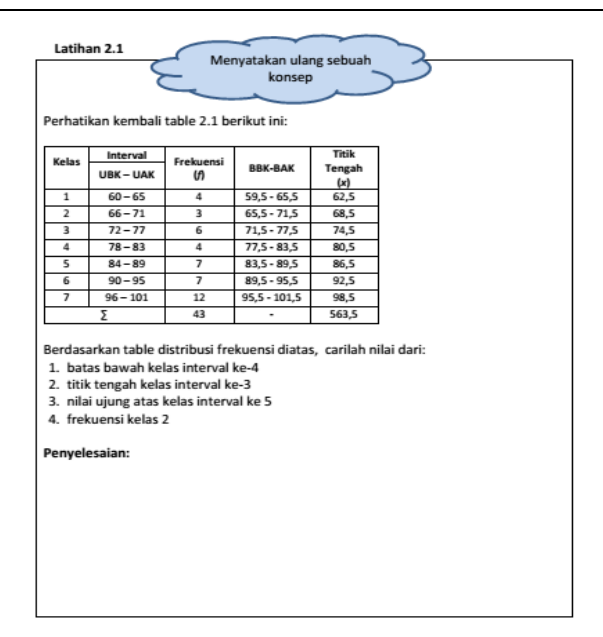

Gb 12. Latihan Kemampuan Menyatakan Ulang Sebuah Konsep

Gambar 11 adalah salah satu contoh soal untuk mengembangkan kemampuan menyajikan konsep dalam berbagai konsep dalam bentuk representasi matematis, sedangkan gambar 12 adalah contoh salah satu soal untuk mengembangkan kemampuan menyatakan ulang sebuah konsep. Kedua soal tersebut tetap atau tidak ada revisi. Soal telah sesuai dengan indicator, bahasa jelas, dan cukup data untuk dikerjakan.

\section{SIMPULAN}

Berdasarkan hasil pengembangan dan hasil uji coba yang telah dilakukan kepada ahli, maka dapat disimpulkan bahwa bahan ajar Statistika ini dapat digunakan untuk mengembangkan kemampuan pemahaman matematis mahasiswa pada mata kuliah Statistika dengan katagori sangat kuat.

\section{DAFTAR PUSTAKA}

Amalia P.R., Wuryanyo, Sukestiyarno Y. L. 2016. Pengembangan Modul Matematika Berbasis Multi Level Pada Materi Aritmetika Sosial Sekolah 
untuk Meningkatkan Jiwa Kewirausahaan. Unnes Journal of Mathematics Education (138-145)

Delekori Alfonsus, Yenni, Badawi Achmad. 2014. Efektifitas Model Pembelajaran Kooperatif Tipe Teams Games Tournament terhadap kemampuan Pemahaman Konsep matematika Siswa Kelas VIII SMP Negeri 20 Tangerang. Skripsi Universitas Muhammadiyah Tangerang : Tidak diterbitkan.

Dharma, Surya. 2008. Penulisan Modul. Jakarta : Direktorat Tenaga Kependidikan.

Khomsiatun Siti, Renawati Heri. 2015. Pengembangan Perangkat Pembelajaran

Dengan Penemuan Terimbing untuk Meningkatkan kemampuan Pemecahan Masalah. Jurnal Riset Pendidikan Matematika, Vol 2 No 1, Mei 2015 (92-106)

Ningrum Widaningsih, Yenni. 2016. Perbandingan Kemampuan Pemahaman Matematis Siswa antara yang mendapat Model Pembelajaran Course Riview Horay dan Numbered Head Together. Jurnal Penelitian dan Pembelajaran Matematika. Volume 9 Nomor 1. Febuaro 2016 (116-123)

Prastowo. 2011. Panduan Kreatif Membuat Bahan ajar Inovatif, Yogyakarta: Diva Press

Safitri Prahesti Tirta, 2016. Pengembangan Bahan Ajar matematika Level IGCSE Berbasis Tugas terstruktur Bagi mahasiswa Calon Guru Matematika. JPPM Vol. 9 No 1

Sudarwan Robert edy, Retnawati Heri. (2015). Pengembangan Perangkat Assesment Pembelajaran Matematika Pokok Bahasan Geometrid dan Pengukuran SMP/MTs. Jurnal Riset Pendidikan Matematika. Vol 2. Nomor 2. November 2015 (251-261).

Yenni, Komalasari Risna. 2015. Pengaruh Model Pembelajaran Learning Cycle Terhadap Kemampuan Pemahaman dan Koneksi Matematis Siswa SMP. Kalamatika Jurnal Pendidikan Matematika. Vol 1 No 1 April 2016 (71-83) 